\title{
OBITUARIES
}

\section{Prof. J. Bayley Butler}

The death of Prof. James Bayley Butler, emeritus professor of zoology, University College, Dublin, on February 21, in his eightieth year, has removed from the academic life of Dublin a distinguished and genial man. It is true to say that his life was varied, active and a very happy one. Born in India, educated in England and Ireland, he followed his medical course in the Catholic University of Ireland and graduated with both the M.B. and M.A. degrees. He was singled out for an academic life and was appointed as a tutor in anatomy in his Alma Mater, gaining the reputation of a gifted teacher and dissector. On the establishment of the National University of Ireland, Dr. Bayley Butler was appointed assistant to Prof. George Sigerson, poet and zoologist, at University College, Dublin. Some years later he became professor of botany in the same College, but he succeeded Sigerson on the latter's retirement in 1922. During the First World War he saw service with the Royal Army Medical Corps.

Prof. Bayley Butler was a member of the Royal Irish Academy, serving three periods on its Council; he was also a member of the Fauna and Flora Committee. At the time of his death he was vice-president and member of the Council of the Royal Dublin Society. He was one of the prime movers of its Bicentenary Exhibition in 1931 and was associated with subsequent exhibition meetings. $\mathrm{He}$ had a long association with the Royal Zoological Society, Dublin, serving on its Council since 1912. Later, he was to become one of the Society's honorary vice-presidents.

Prof. Bayley Butler is perhaps best known as an applied zoologist. He gained a remarkable reputation as an expert witness in court cases, both in Irolend and abroad. In his later years he became interested in the distribution and control of wood-boring beetles and of Serpula lacrymans, the cause of dry rot, and became scientific adviser to an Irish firm manufacturing both insecticides and fungicides. His work on the chytridiacean parasite, Catenaria anguillulae, in the ova of Fasciola hepatica, is known to parasitologists.

One could speak at great length of Dr. Bayley Butler's remarkable versatility. He sold the patent of a resinous water-proofing material used in the preparation of field maps to the American Army during the Second World War. His work at Glenlion, Baily, Co. Dublin, is familar to both architect and botanist. He designed and built his home by direct labour, and the Roman and Alpine gardens were opened each year for the Jubilee Nurses' Fund and had the reward of remarkable attendances. For some years, though in failing health, he was engaged in writing his autobiography. It is hoped that the records of a very remarkable life will be published later.

This appreciation should not end without mention of a very impertant side of Prof. Bayley Butler's personality, the professor-student relationship, a relationship inclined to be overlooked to-day with increasing student numbers. One remembers the expeditions to Dalkey Island, the Christmas parties at his home in Ranelagh Road and, later, the garden parties at Glenlion, Baily, Co. Dublin, where frog, cockroach and snail races were novel features of very enjoyable afternoons. Dr. Bayley Butler was never happier than as host on such occasions.

He will be remembered by his students, colleagues and friends as a man of remarkable intellect, of great understanding and gentle disposition.
C. F. HumpHrIEs
Dr. A. H. R. Goldie, C.B.E.

DR. A. H. R. GoldIE, who died at his home in Stirling on January 24, aged seventy-five, was deputy director in charge of research when he retired from the Meteorological Office in 1953.

With the Dux Medal from his school at the Harris Academy, Dundee, and a first-class honours degree in mathematics and natural philosophy from the University of St. Andrews in 1909, Goldie went on to St. John's College, Cambridge, where he was a wrangler in the mathematical tripos of 1913. Deciding on meteorology as a career, he spent two years in weather forecasting and the Meteorological Office Observatories at Falmouth and Eskdalemuir before he joined the Meteorological Section of the Royal Engineers, newly formed under Capt. (later Lt.-Col.) F. Gold. In his duties with the British Army, first in France and later on the Italian front, Goldie enthusiastically applied. Gold's recently developed theory of the gradient wind to the preparations of reports for the artillery, a practice which was soon acknowledged by the British and German Army Staffs as providing accurate information for shooting when balloon ascents could not be made.

When he returned to the Meteorological Office in 1919 with the rank of major, Goldie was for five years in control of local forecasting centres at civil and military airfields before he was appointed superintendent of the Meteorological Office, Edinburgh, where he remained until 1938. This was Goldie's most productive scientific period. His early interest in what goes on in the upper air above weather systems had matured, and his keen powers of interpreting observational data (which had led him in 1923 to direct attention for the first time to the occurrence of the laminated tropopause) backed by a thorough grasp of the various problems he tackled bore fruit in a valuable series of papers. He wrote five Geophysical Memoirs on the distribution of wind and rainfall around depressions and on the kinematical features of depressions treated as vortices; he also contributed papers to the Quarterly Journal of the Royal Meteorological Society and to the Transactions and Proceedings of the Royal Society of Edinburgh. These were on such diverse themes as "Waves at an Approximately Horizontal Surface of Discontinuity in the Atmosphere", "The Structure and Movement of the Atmosphere as Affected by Diurna] Variations" and "The Electric Field in Terrestrial Magnetic Storms". Though well enough known to the staff at the Observatories at Lerwick and Eskdalemuir which he controlled at that time, the insight into geomagnetic phenomena shown in the last-named paper surprised many of Goldie's meteorological contemporaries: its value as a contribution to geomagnetic theory was recognized by Goldie's appointment as secretary of the International Association of Terrestrial Magnetism and Atmosphere Electricity, a post he held for eleven years.

In 1938 Goldie became the first assistant director (research) in the Meteorological Office, and in this appointment, even with the administrative responsibility of controlling the work of the Instruments, Climatology and Marine Branches added soon after the outbreak of the Second World War, Goldio continued to mako important contributions to meteorological theory and practice. He produced an explanation of how aireraft. condensation trails are formed, and this led to a means of forecasting the altitudes where they could occur and to the adoption of rules for airerews on how to avoid making 
them. When he could return to his own field of interest after the War, Goldie used the new measurements of humidity made at great heights by the Meteorological Research Flight to deduce the large-scale flow of the atmosphere from the troposphero over the tropies into the stratosphere above middle latitudes, and this in turn led to several papers on the atmospheris circulation at high levels.

In 1936 Goldie was awvarded a D.Sc. by the University of St. Andrews and was promoted to deputy diroctor (research) in 1946 with the rank of deputy chief scientific officer; he was appointed C.B.E. in 1951. He had served on the Council of the Royal Meteorological Society and as vice-president of the Royal Society of Edinburgh. Always a gentle, friendly and unassuming man with a wide interest in people and the world around him, Goldie in his younger days enjoyed tennis, badminton and long walks in the hills; but fishing was his real pastime. As a boy he often accompanied his father, the Rev. Andrew Goldie, on excursions from the manse into the hills around Glenisla, and he shared the quiet satisfaction of landing a trout from the loch. That kind of quiet enjoy. ment of unpretentious things continued with him through life. Goldie was twice married: in 1928 to Marion Wilson, who was widely known for her devoted work for the Meteorological Office staff evacuated to Stonehouse in the war years; she died in 1948. In 1952 he married Helen Carruthers, author, with Dr. C. E. P. Brooks, of the Handbook of Statistical Method in Meteorology. Thero were no children.

J. M. StAGg

\section{Dr. A. Elek}

Dr. Adalbert Elek was born in Hungary on May 3, 1887, and obtained his education and degrees in his home country.

After going to the United States he became microanalyst at the Rockefeller Institute in New York, where he introduced micro-analytical procedures for all the elements following closely the book by F. Progl. He also devoloped numerous procedures in this field which are still used by the micro-analyst.

In 1948 he moved to California, where he established in Los Angeles his own micro-analytical laboratory on a consulting basis. He died on January 4, 1964, but will be remembered by all microchemists in the United States as probably the first chomist using micro-analytical procedures continuously with success. He was a member of the American Microchemical Society.

\section{NEWS and VIEWS}

The Royal Irish Academy :

Officers

Tre following have been elected officers of the Royal Irish Academy: President, Prof. J. Doyle, emeritus professor of botany in University College, Dublin; Treasurer, Dr. V. C. Barry; Secretary of the Academy and Secretary for Irish Studies, Dr. B. O. Cuiv; Secretary of the Science Committee, Dr. P. J. Nolan; Secretary for Polite Literature and Antiquities, Mr. J. J. Tierney.

Members

The following were elected new members of the Academy: Dr. J. S. R. Chisholm, Dr. M. de Paor, Mr. R. H. M. Dolley, Dr. C. Kemball, Dr. B. Spencer, Dr. H. Wagner, Mr. W. A. Watts.

Honorary Members

The following were elected honorary members in the Section of Science: Prince Louis V. P. R. de Broglio, Prof. Melvin Calvin, Dr. F. H. C. Crick, Prof. Werner Heisenberg.

\section{Council Members}

The following were elected to the Science Section of the Council: Dr. V. C. Barry, Dr. R. C. Geary, Dr. J. N. Grainger, Rev. R. E. Ingram, Dr. C. Lanczos, Rev. J. R. McConnell, Dr. P. J. Nolan, Dr. N. A. Porter, Dr. J. L. Synge, Dr. E. T. S. Walton, Dr. A. E. Went.

\section{International Academy of Astronautics :}

Corresponding Members

THE following have been elected corresponding members of the International Academy of Astronautics of the International Astronautical Federation.

Basic Sciences Section: Dr. Lloyd V. Berkner, Graduate Research Center of the Southwest, Dallas, Texas; Prof. $J$. Coulomb, Centre National d'Etudes Spatiales, Paris; Dr. H. Elliot, Department of Physics, Imperial College of Science and Technology, London; Dr. George Gamow, Department of Physies and Astrophysies, University of Colorado, Boulder; Prof. Samuel Herrick, University of California in Los Angeles; Dr. Chia-Chiao Lin, Massachusetts Institute of Technology, Cambridge, Mass.; Dr. A. P. Mitra, National Physical Laboratory, Now Delhi;
Prof. Tatsuzo Obayashi, Ionosphere Research Laboratory, Kyoto University, Kyoto; Prof. Yngve Ohman, Stockholm Observatory, Saltsjöbaden; Prof. P. Swings, Institute of Astrophysics, Cointe-Sclessin; Dr. John W. Townsend, jun., National Aeronautics and Space Administration Goddard Space Flight Center, Greenbelt, Md.; Prof. C. E. von Weizsäcker, University of Hamburg.

Engineering Sciences Section: Dr. A. K. Oppenheim, University of California, Berkeley, Cal.; Dr. Simon Ramo, Bunker-Ramo Corp., Canoga Park, Cal.; Prof. Robert Sauer, Mathematisches Institut der Technischen Hochschule, Munich; Dr. W. R. Sears, Graduato School of Aoronautical Engineering, Cornell University, Ithaca, N.Y.

Life Sciences Section: Dr. W. R. Adey, Space Biology Laboratory, University of California at Los Angeles Health Sciences Center; Wing Commander P. Howard, Royal Air Force Institute of Aviation Medicine, Farnborough; Prof. E. H. Graul, Strahleninstitut dor PhilippsUniversität Marburg/Lahn; Dr. Erwin A. Lauschner, Institute of Aerospace Medicine, German Air Force, Fürstenfeldbruck.

\section{Salk Institute for Biological Studies :}

Dr. Leo Szilard

Dr. Leo SzILARD, one of the world's most ominent scientists, has been appointed Resident Fellow of the Salk Institute for Biological Studies, San Diego, California, as of April 1, 1964.

Dr. Szilard's achievements as a theoretical and nuclear physicist have brought him international recognition and fame, especially when, during 1939-42, he and Enrico Fermi designed the first chain reaction systom - that of uranium and graphite-used in the atomic pile. After the Second World War, Dr. Szilard turned from the problems of physics to the life sciences, becoming professor of biophysics in the University of Chicago. Dr. Szilard's work in recent years has centred on problems relating to induced enzymo formation in bacteria, antibody formation in mammals, the goneral problem of ageing, and the molecular basis of memory. It is in order to continue his own work in collaboration with the othor Follows of the Institute that Dr. Szilard has taken up residence in San Diego. Dr. Szilard's achievements in the field of 